\title{
Evidence for apoptosis correlated with mortality in the giant black tiger shrimp Penaeus monodon infected with yellow head virus
}

\author{
Kornnika Khanobdee ${ }^{1}$, Chumporn Soowannayan ${ }^{1}$, T. W. Flegel ${ }^{1}$, Sukathida Ubol ${ }^{2}$, \\ Boonsirm Withyachumnarnkul ${ }^{1, *}$
}

${ }^{1}$ Centex Shrimp, and ${ }^{2}$ Department of Microbiology, Faculty of Science, Mahidol University, Rama 6 Rd., Bangkok 10400, Thailand

\begin{abstract}
Histological, cytochemical and ultrastructural changes in giant black tiger shrimp Penaeus monodon were investigated at various time intervals after injection with yellow head virus (YHV). Hemocytes, lymphoid organs (LO) and gills were the main focus of the study. After injection with YHV, onset of mortality varied from $36 \mathrm{~h}$ onward. By normal hematoxylin and eosin staining, the 3 tissues showed clear and increasing prevalence of nuclear condensation, pyknosis and karyorrhexis from approximately $36 \mathrm{~h}$ post-injection (p.i.) until death, although pathology was evident in the LO as early as $12 \mathrm{~h}$ p.i. in some shrimp. By nuclear DNA staining with 4',6-diamidino-2-phenylindole (DAPI) and by specific labeling of $3^{\prime}-\mathrm{OH}$ ends of nuclear DNA using a technique called terminal deoxynucleotidyl transferase-mediated deoxy-UTP nick-end labeling (TUNEL), cells of the 3 tissues showed evidence of chromatin condensation and DNA fragmentation, respectively. Both are generally considered to be characteristic of apoptosis. In addition to TUNEL labeling, evidence for DNA fragmentation was supported by the appearance of 200 base pair DNA ladders at approximately $48 \mathrm{~h}$ p.i. in hemocytes of YHV-infected but not uninfected shrimp. Transmission electron microscopy (TEM) of LO tissue revealed features of apoptosis in tissues of YHV-infected shrimp only. These included marginated, condensed and fragmented chromatin without concurrent cytoplasmic damage. Histological, cytochemical, ultrastructural and biochemical data were consistent with the hypothesis that widespread and progressive apoptosis occurred in susceptible shrimp infected with YHV. Although no specific tests were carried out to determine whether this purported apoptosis was the cause of mortality, moribund shrimp had extensive deterioration of vital tissues such as the hemolymph, gills, heart and LO, suggesting that many essential bodily functions had been severely compromised. This probably resulted in the gross signs of lethargy and weakness seen, and it is reasonable to suggest that further, progressive deterioration could have led to the collapse of vital functions followed by death.
\end{abstract}

KEY WORDS: Yellow head virus $\cdot$ Yellow head disease $\cdot$ Penaeus monodon $\cdot$ Apoptosis Resale or republication not permitted without written consent of the publisher

\section{INTRODUCTION}

Yellow head disease (YHD) in cultured black tiger shrimp Penaeus monodon was first noticed in central Thailand by Limsuwan in 1991 (Limsuwan 1991). The causative agent was found to be an RNA-virus com-

${ }^{*}$ Corresponding author. E-mail: boonsirm@asianet.co.th monly known as yellow head virus (YHV) (Boonyaratpalin et al. 1993, Chantanachookin et al. 1993). On the basis of morphology of negatively stained virions by transmission electron microscopy (TEM) (Wongteerasupaya et al. 1995), RNA content (Wongteerasupaya et al. 1995) and sequence information, YHV is a positivesense, single-stranded RNA virus most likely related to the coronaviruses (Cowley et al. 1999, 2000a,b, Tang \& Lightner 1999). 
YHV infects cells of both ectodermal and mesodermal origin (Boonyaratpalin et al. 1993, Chantanachookin et al. 1993, Kasornchandra et al. 1995). By TEM, it is a 150 to $170 \mathrm{~nm}$ by 40 to $50 \mathrm{~nm}$ rod-shaped virus with a continuous fringe of spike-like projections radiating out approximately $11 \mathrm{~nm}$ from the outer envelope (Wongteerasupaya et al. 1995). The lymphoid organ (LO) of moribund shrimp suffering from YHD usually has extensive abnormalities, including many degenerated cells in the stromal matrix of the tubules. These have condensed pyknotic and karyorrhectic nuclei, and cytoplasmic basophilic inclusions (Chantanachookin et al. 1993, Lightner 1996). Other tissues, such as the interstitial tissues of the hepatopancreas, connective tissue underlying the midgut, cardiac tissue, hematopoietic tissue, hemocytes and gill tissue, also had similar pathological features (Boonyaratpalin et al. 1993, Lightner 1996).

Despite severe tissue damage by YHV, no inflammatory response has ever been detected in the tissues of infected shrimp (Flegel \& Pasharawipas 1998). This suggests that cell death caused by YHV may be due to apoptosis rather than necrosis. The occurrence of apoptosis in shrimp or any other crustacean has not been substantiated, although there are some recent suggestions in the literature that cell death by apoptosis is associated with viral infections in shrimp (Flegel \& Pahsarawipas 1998, Henderson \& Stuck 1999, Anggraeni \& Owens 2000). Apoptosis is also involved in tissue and organ differentiation, as it is in other animals including a number of arthropods (Kerr et al. 1972).

The small amount of experimental work that has been done so far concerning apoptosis in shrimp viral infections has used white spot syndrome virus (WSSV) and has depended largely on use of terminal deoxynucleotidyl transferase (TdT)-mediated deoxy-UTP nick-end labeling (TUNEL) as an indication of DNA fragmentation (Henderson \& Stuck 1999, Anggraeni \& Owens 2000, Sahtout et al. 2001). In this study, we have used several measures to determine whether there is evidence of apoptosis in shrimp infected with YHV.

\section{MATERIALS AND METHODS}

Grossly healthy Penaeus monodon, 10 to 15 g, were stocked in 6 concrete circular tanks of approximately $2.0 \mathrm{~m}$ diameter containing $10 \%$ sea water at a $0.80 \mathrm{~m}$ depth. Each tank contained 100 shrimp fed commercial feed pellets at $3 \%$ body weight daily. Air stones were used to ensure a dissolved oxygen level above 5 ppm. The shrimp were acclimated for $3 \mathrm{~d}$ before experiments were begun. They were then divided into 3 groups of 2 tanks each, including an untreated control group, a lobster hemolymph buffer (LHB)-injected control group and a YHV-injected group. LHB was prepared using the method described by Paterson \& Stewart (1974).

A crude extract of YHV was prepared from hemolymph of moribund shrimp from a natural YHD outbreak in a culture pond in the following way. Hemolymph was withdrawn from the ventral hemolymph sinuses of the shrimp, diluted 1:100 with LHB and filtered through a sterile $0.45 \mu \mathrm{m}$ membrane filter. All processes were carried out under sterile conditions and the diluted YHV crude extract was kept in aliquots at $-80^{\circ} \mathrm{C}$ until used.

The LHB-injected and YHV-injected shrimp were individually injected with $0.1 \mathrm{ml}$ LHB and YHV crude extract, respectively, into the abdominal muscle. Twenty animals from each group, including the intact control, were sampled at 0, 6, 12, 24, 36, 48 and $60 \mathrm{~h}$ following the injection. From the sampled shrimp, LOs, gills and hemocytes were isolated immediately and processed for standard histology using hematoxylin and eosin (H\&E) staining, for staining with 4',6diamidino-2-phenylindole (DAPI) and for labeling with TUNEL. DNA extracts from the hemocytes were also assayed by gel electrophoresis. In addition, a few other tissues were fixed and processed for standard histology using H\&E staining.

For DAPI staining, tissues fixed with Davidson's fixative were embedded in paraffin and $5 \mu \mathrm{m}$ sections were prepared using standard procedures (Bell \& Lightner 1988). For hemocytes, thin smears were prepared on clean glass slides. The specimens were then washed and flooded with DAPI solution $\left(1 \mu \mathrm{g} \mathrm{ml}^{-1}\right)$ and incubated for $15 \mathrm{~min}$ at $37^{\circ} \mathrm{C}$ inside a small humidified chamber covered with aluminum foil. After incubation, the specimens were washed once with methanol and 1 drop of anti-fade solution (Vectashield, H-1000, Vector Laboratories Inc., Burlingame, California, USA) was added before mounting to examine for chromatin condensation and disintegration under a fluorescence microscope with a 340/380 nm excitation filter.

In the TUNEL procedure (Garvieli et al. 1992), tissues and hemocyte smears were processed as for DAPI staining. The sectioned tissues were de-paraffinized, rehydrated, immersed in $4 \%$ paraformaldehyde in phosphate-buffered saline (PBS) for $15 \mathrm{~min}$ at room temperature, washed in PBS $(2 \times 5 \mathrm{~min})$ and digested with $20 \mu \mathrm{g} \mathrm{ml}^{-1}$ Proteinase $\mathrm{K}$ at the volume of $100 \mu \mathrm{l}$ per tissue section. The sections were allowed to react with the enzyme for $15 \mathrm{~min}$ at room temperature before being washed with PBS. They were then postfixed with $4 \%$ paraformaldehyde and washed in PBS at room temperature. Excess liquid was removed by tapping the slide and the tissue was covered with $100 \mu \mathrm{l}$ of equilibration buffer at room temperature for 
$10 \mathrm{~min}$. The tissue was then covered with $50 \mu \mathrm{l}$ of the enzyme TdT diluted in incubation buffer ( $45 \mu \mathrm{l}$ of equilibration buffer, $5 \mu \mathrm{l}$ of nucleotide mix and $1 \mu \mathrm{l}$ of $25 \mathrm{U}$ $\mathrm{\mu l}^{-1}$ of TdT enzyme). Sections were covered with a plastic coverslip to ensure even distribution of the reagent and incubated at $37^{\circ} \mathrm{C}$ for $60 \mathrm{~min}$ inside a humidified chamber to allow the tailing reaction to occur. Exposure to light was prevented during this and following steps by covering the chamber with aluminum foil.

After the 60 min incubation, the reaction was stopped by placing the slides in a coplin jar containing $40 \mathrm{ml}$ of $2 \times$ saline sodium citrate (SSC) buffer for $15 \mathrm{~min}$ at room temperature. The slides were washed in fresh PBS to remove unincorporated fluorescein-deoxy-UTP. The tissue was counterstained by immersing the slides in $40 \mathrm{ml}$ of a freshly prepared propidium iodide solution ( $1 \mathrm{\mu g} \mathrm{ml}^{-1}$ in PBS) for $15 \mathrm{~min}$ at room temperature. The slides were then washed in de-ionized water $(3 \times$ $5 \mathrm{~min}$ ) and 1 drop of anti-fade (Vectashield, H-1000) was added to the tissue before mounting. The slides were immediately observed under a fluorescence microscope using a standard fluorescent filter set to view green fluorescence of the nuclei at $520 \pm 20 \mathrm{~nm}$ for a positive indication of DNA fragmentation and red fluorescence of propidium iodide at $>620 \mathrm{~nm}$ for a negative indication of DNA fragmentation.

For hemolymph smears, the TUNEL assay was performed according to the manufacturer's instructions (Promega, Madison, Wisconsin, USA), with some modification to the permeabilization step. In this step, Triton X-100 was used at $1.0 \%(\mathrm{v} / \mathrm{v})$ in PBS on ice for $5 \mathrm{~min}$, followed by Proteinase K at $50 \mu \mathrm{g} \mathrm{ml}^{-1}$ for $15 \mathrm{~min}$ at room temperature. For positive controls, a smear of normal shrimp hemocytes treated with DNase I was used, as recommended in the instruction manual. The samples were analyzed by fluorescence microscopy, by which apoptotic nuclei stained green and nuclei of normal cells stained red with the propidium iodide counterstain.

Included in each preparation were positive and negative control tissues. The positive controls comprised normal tissues pre-treated with DNase I (Life Technologies, Inc., Frederick, Maryland, USA) to digest the nuclear DNA into fragments before identical processing. The negative controls comprised normal tissues treated identically but without addition of TdT enzyme, except for hemocytes, where the TdT enzyme was added to the normal cell control preparation.

YHV-infected tissues were also studied by TEM. LOs were fixed in $2.5 \%$ glutaraldehyde, post-fixed in $1 \%$ $\mathrm{OsO}_{4}$, dehydrated in an acetone series and embedded in Araldite-502 resin. Ultra-thin sections of silver-gray interference (60 to $90 \mathrm{~nm}$ ) were collected on copper grids and stained with uranyl acetate and lead citrate before viewing and photographing under a TEM (Hitachi H-300) at an acceleration voltage of $75 \mathrm{kV}$.

For gel electrophoresis, pooled hemolymph of 3 shrimp from each group were used and total nucleic acid was extracted by the conventional phenol/chloroform extraction method, as described by Sambrook et al. (1989), with some modification. Pooled hemolymph (approximately $4 \mathrm{ml} \mathrm{group}^{-1}$ ) was centrifuged at $400 \times g$ at $4^{\circ} \mathrm{C}$ for $10 \mathrm{~min}$ and cell pellets were collected. For each pooled sample, 1 volume of lysis buffer $(50 \mathrm{mM}$ Tris- $\mathrm{HCl}_{1} \mathrm{pH}$ 9.0, $100 \mathrm{mM}$ EDTA, $50 \mathrm{mM} \mathrm{NaC}$; and $2 \%$ sodium dodecyl sulfate) containing $20 \mathrm{\mu g} \mathrm{ml}^{-1}$ of Proteinase $\mathrm{K}$ was added in 2 times the amount of the pellet volume. The mixture was incubated at $65^{\circ} \mathrm{C}$ for $1 \mathrm{~h}$ and then incubated further at room temperature overnight. To remove digested proteins, an equal volume of phenol was added before centrifugation at $5000 \times g$ and $4^{\circ} \mathrm{C}$ for $10 \mathrm{~min}$. The supernatant was collected and the step repeated once more before adding an equal volume of phenol:chloroform $(1: 1)$ followed by further centrifugation at $5000 \times \mathrm{g}, 4^{\circ} \mathrm{C}$, for $10 \mathrm{~min}_{\text {; }}$ the supernatant containing nucleic acid was then collected and precipitated in 2 volumes of $100 \%$ ethanol at $-20^{\circ} \mathrm{C}$ overnight. This nucleic fraction was washed twice by centrifugation with $1 \mathrm{ml}$ of $70 \%$ ethanol at $10000 \times g, 4^{\circ} \mathrm{C}$, for $15 \mathrm{~min}$ and dried at room temperature. The DNA pellet was then dissolved in $50 \mu \mathrm{l}$ of Tris buffer, kept at $37^{\circ} \mathrm{C}$ for $30 \mathrm{~min}$ and then stored at $4^{\circ} \mathrm{C}$ until used.

Agarose gel electrophoresis used $1.8 \%$ agarose gels. Markers comprised $\lambda$ DNA cut with EcoRI and HindIII and a 123 base pair (bp) marker (ladder marker). All samples were mixed with loading buffer (10 mM EDTA, $0.25 \% \mathrm{w} / \mathrm{v}$ bromophenol blue and $50 \% \mathrm{v} / \mathrm{v}$ glycerol) before loading. The gel was run at $50 \mathrm{~V} \mathrm{~cm}^{-1}$ for $80 \mathrm{~min}$ and stained with ethidium bromide. The results were examined on a UV transilluminator and photographed.

\section{RESULTS}

Light microscopy (LM) of gills, LO and hemocytes revealed cells with nuclei that had pyknosis, karyorrhexis and chromatin margination (Fig. 1), and with cytoplasm that had vacuolation; the prevalence of these cells progressively increased from $12 \mathrm{~h}$ postinfection (p.i.). The LO was the first organ attacked by YHV and had the highest degree of destruction, with most of the pyknotic and karyorrhectic nuclei occurring in the LO tubules and very few in LO spheroids. Both the YHV-injected and uninjected shrimp had these spheroids among the LO tubules (Fig. 1, tA, tB) and these were classified as type A $(+\mathrm{A})$, type $\mathrm{B}(+\mathrm{B})$ and type $C(+C)$ based on the degree of vacuolization as described by Hasson et al. (1999). 


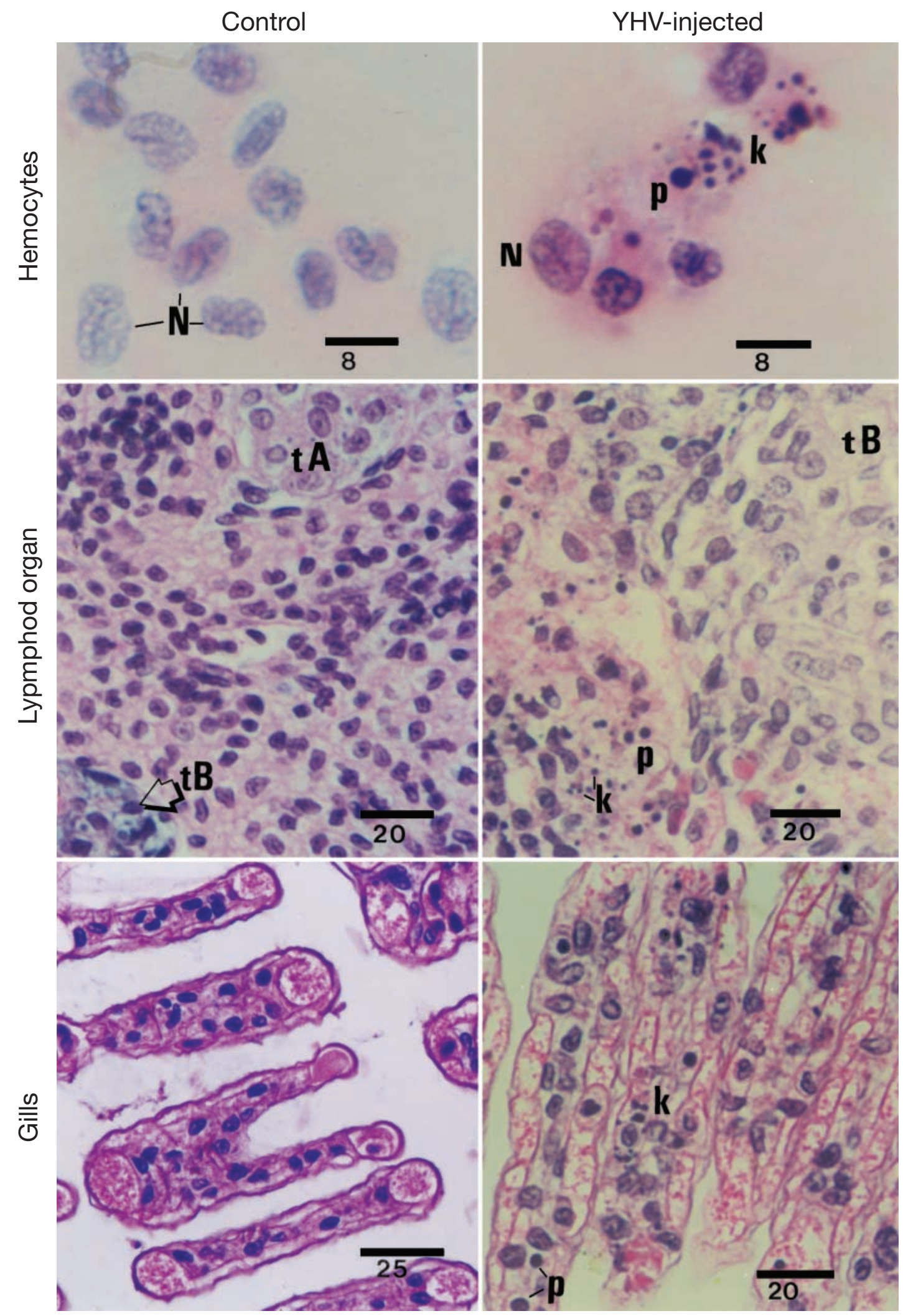

Fig. 1. Light micrographs of normal and yellow head virus (YHV)-infected hemocytes, lymphoid organ (LO) and gills of Penaeus monodon with hematoxylin and eosin (H\&E) staining. These are arranged in a grid contrasting pairs of normal and YHV-infected specimens for 3 tissue types. Abnormal-shaped nuclei with pyknosis (p) and karyorrhexis (k) can be seen in all 3 YHV-infected but not in normal tissue types, except for LO spheroids. LO spheroid examples (type A [tA], type B [tB]) can be seen in the control shrimp (tA, upper right, and $\mathrm{tB}$, lower left part of the middle panels) and in YHV-infected shrimp (tB, right half of photomicrograph), both containing relatively few karyorrhectic and pyknotic nuclei. Many can be seen in the LO tubules of the YHVinjected shrimp (left half of the photomicrograph). In the gills, some of the abnormal nuclei can be seen in the pillar epithelium and some in the hemolymph vessels (probably hemocytes). All scale bars shown are in micrometers 
With DAPI staining, nuclei stand out since the stain is specific for nuclear DNA. Typical pyknotic and karyorrhectic nuclei were observed in the hemocytes, LO and gills of YHV-infected shrimp, whereas normal nuclei were observed in the same tissues of control groups (Fig. 2). At the earliest, abnormal nuclei were observed at $12 \mathrm{~h}$ p.i. and they became more abundant thereafter until death.

By TUNEL assay, gills and hemolymph from the untreated and LHB-injected negative control shrimp reacted negatively except when treated with DNase before staining (i.e. positive control group) (Fig. 3). A curious phenomenon was the consistent absence of TUNEL-stained nuclei in the DNase I-treated LO tissue, even though the cell nuclei of immediately surrounding tissue in the same slides gave a normal positive reaction (Fig. 3). In spite of this, some TUNELpositive nuclei were seen in LO spheroids in both normal and YHV-injected shrimp. Despite this anomaly, the general reaction with surrounding tissue and contrasts with YHV-injected and uninjected shrimp could still be compared. In YHV-infected shrimp, the earliest positive TUNEL reaction (green fluorescence) was observed in only a few cells of the LO (outside spheroids) at $12 \mathrm{~h}$ p.i., but stained nuclei became progressively more prevalent thereafter in the LO, hemocytes, gills and other target tissues. The relative number of positive-staining cells in the gills was generally less than in the LO.

The total hemocyte numbers declined rapidly in YHV-infected shrimp and, from $30 \mathrm{~h}$ p.i. onward, the proportion of remaining hemocytes with karyorrhectic and pyknotic nuclei increased with time as detected using LM with H\&E and DAPI staining and TUNEL (Fig. 4). In addition, DNA extracts from hemocytes of YHV-injected shrimp prepared 48 h p.i. had 200 bp ladder patterns (Fig. 5) that were not present in uninjected or LHB-injected shrimp.

By TEM, LOs of the untreated and LHB-injected shrimp contained normal nuclei with heterochromatin in peripheral patches and as a central mass (Fig. 6A). In YHV-injected shrimp, both normal and degenerate LO cells were observed. No YHV particles were observed before $12 \mathrm{~h}$ p.i. At this time (Fig. 6), nuclear chromatin of the infected cells became condensed and marginated in sharply delineated masses abutting the nuclear envelope (Fig. 6B to D). The cytoplasm was also markedly condensed. In spite of these dramatic changes, there was no TEM evidence of viral structures inside these cells, although virions were occasionally seen in intercellular spaces. By 24 to 36 h p.i., when viral structures including complete virions were present (Fig. 7), more abnormal features were detected including some fragmentation of nuclear chromatin, disruption of presumed nucleolar structures and dense nuclear condensation (Fig. 7A). Despite these rather severe pathological changes in the nucleus, the nuclear envelope and cytoplasmic organelles such as mitochondria, ribosomes and rough endoplasmic reticulum (rER) remained relatively intact (Fig. 7A).

Virions in YHV-infected cells were more frequently observed at 48 to 60 h p.i. (Fig. 8), as were condensed nuclei (pyknotic nuclei) (Fig. 8A) and electron-dense, round structures surrounded by narrow electron-lucent spaces (Fig. 8B,C). On the basis of the pathological changes observed during earlier stages of infection, the latter structures were considered to be fragmented nuclei surrounded by cytoplasmic residues (i.e. 'apoptotic bodies' arising from YHV-infected cells). These apoptotic bodies were frequently observed in clusters in intercellular spaces and, together with pyknotic nuclei, were often phagocytosed by neighboring cells (Fig. 8C), where they underwent degenerative changes within phagosomes.

\section{DISCUSSION}

In this study, evidence of apoptosis was found in the hemocytes, LO and gills of YHV-infected shrimp by LM using special nuclear stains to reveal chromatin condensation and DNA fragmentation. Further indications of apoptosis were seen in the LO by TEM. The ultrastructural changes observed were similar to those described for early apoptosis, including nuclear chromatin margination followed by partial and complete chromatin condensation, nuclear budding or fragmentation and the appearance of nuclear fragments, termed apoptotic bodies, surrounded by an envelope (Kerr 1971, Kerr et al. 1972). The cytoplasm is also markedly condensed. Despite severe pathological changes in the nucleus, the nuclear envelope and cytoplasmic organelles such as mitochondria, ribosomes and rER are preserved. In this study, all of these ultrastructural changes characteristic of apoptosis were seen in YHV-infected shrimp cells.

We have no explanation as to why DNase I treatment consistently gave TUNEL-positive results in tissues surrounding the LO but negative results in the LO except for some spheroid cells in both YHV-injected and uninjected shrimp. Anggraeni \& Owens (2000) have reported that TUNEL-positive nuclei are often seen in LO spheroids, where they may represent cells undergoing apoptosis as a normal response to viral infection. Indeed, it has been reported that grossly normal shrimp may be infected with 1 or more viruses without gross signs of disease (Flegel 2001) and it is possible that the spheroids arose from subclinical viral infections present before YHV injection. However, we checked tissue sections (not shown) for YHV using a 


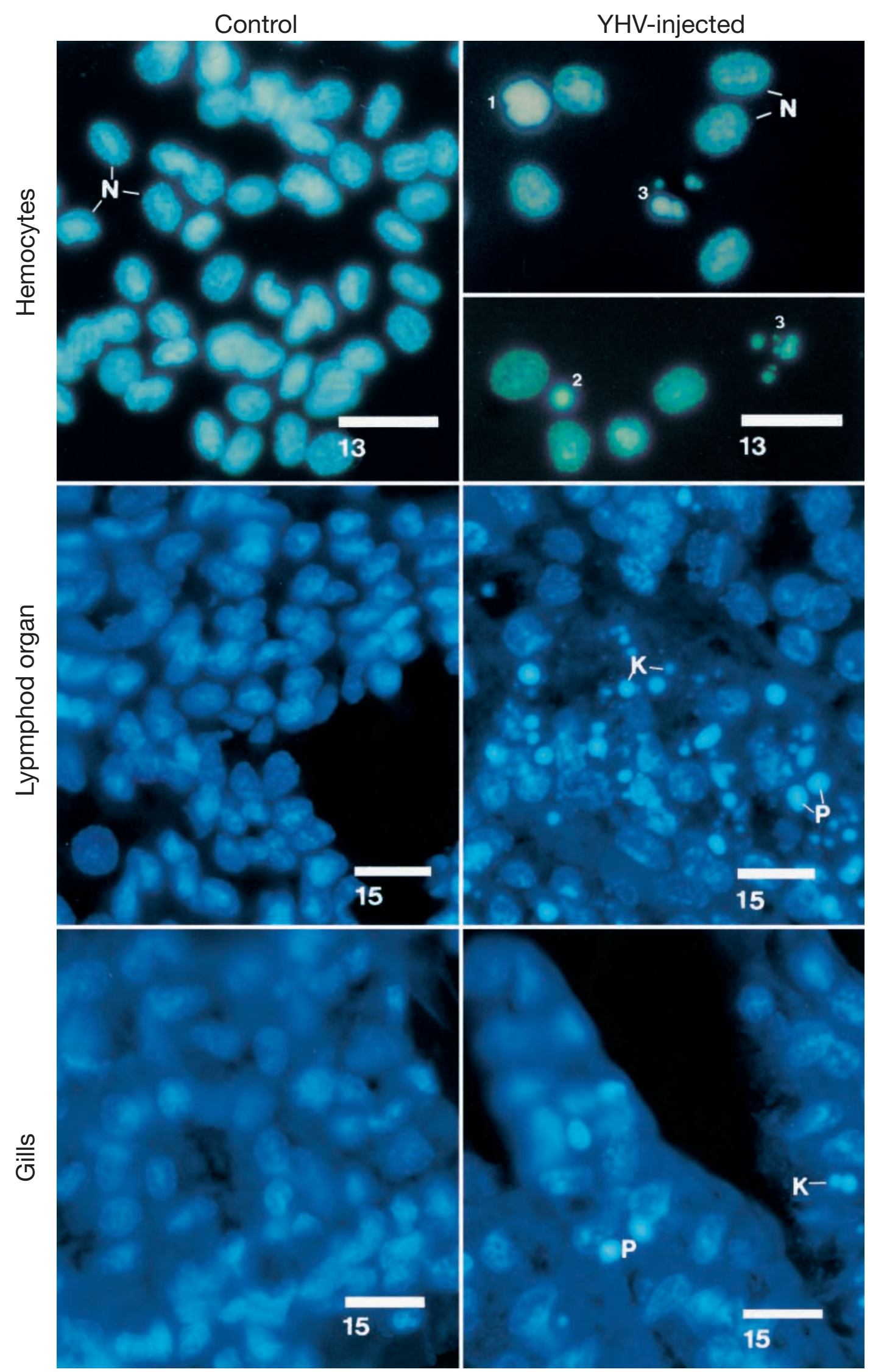

Fig. 2. Fluorescence micrographs of hemocytes, LO and gills of normal and YHV-infected Penaeus monodon stained with 4',6diamidino-2-phenylindole (DAPI). Similar features can be seen as in Fig. 1 except that the nuclei are more clearly resolved and are in various stages of condensation. For the hemocytes, N: normal nuclei; 1 : early condensation; 2 : pyknotic; 3 : karyorrhectic.

For the LO and gills, k: karyorrhexis; p: pyknosis. All scale bars shown are in micrometers 


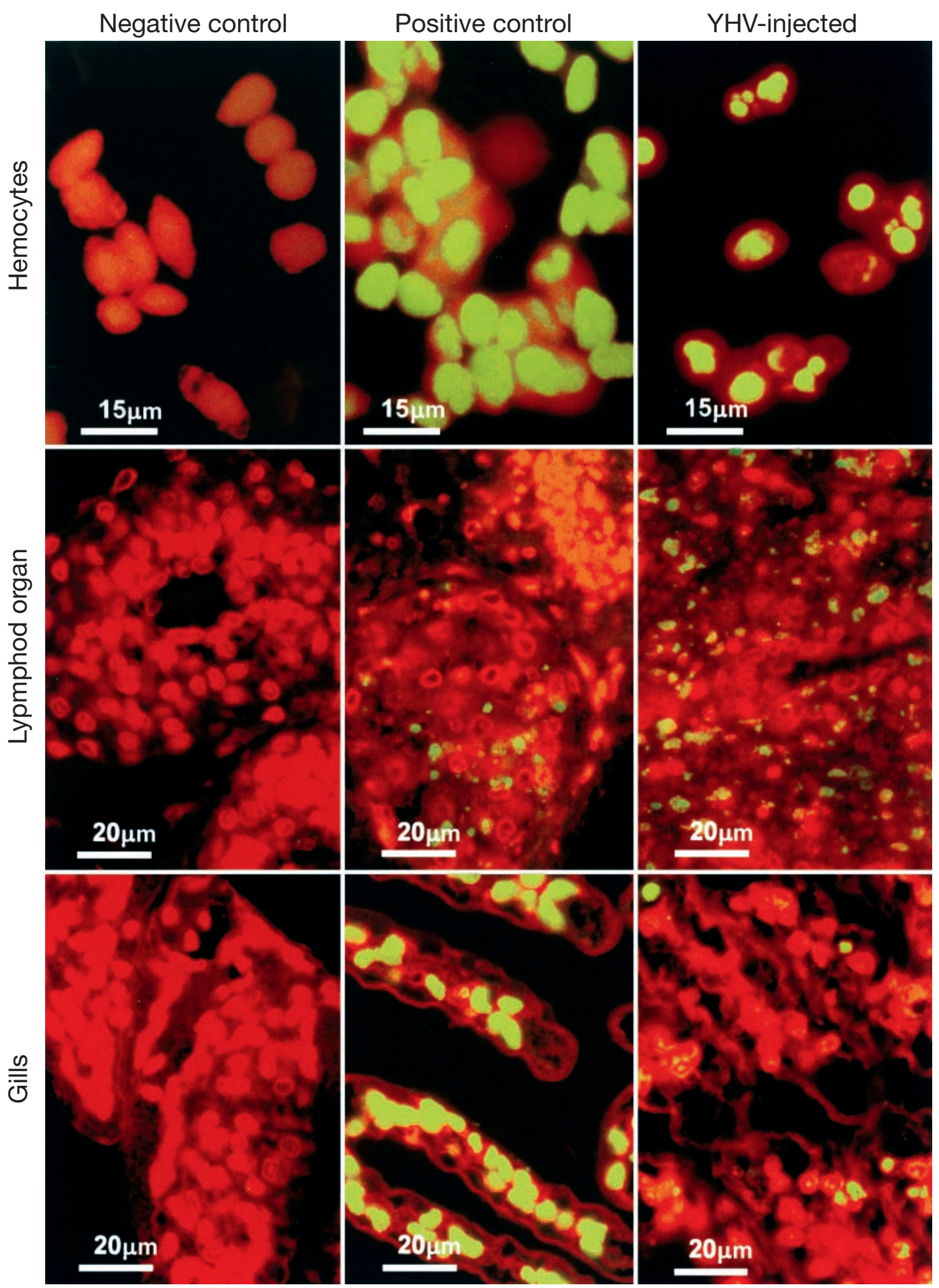

Fig. 3. Fluorescence micrographs of normal and YHV-infected hemocytes, LO and gills of Penaeus monodon with terminal deoxynucleotidyl transferase-mediated deoxy-UTP nick-end labeling (TUNEL). Positive TUNEL yielded yellow to green fluorescence as opposed to red fluorescence of the counterstain. The LO and gill tissues in the figure were photographed from slides of contiguous tissue sections so that photographs of the positive control for LO and gill tissue were made from the same section and slide preparation while the hemocyte preparations were made from smears. Positive TUNEL is seen only in the positive control and YHV-infected tissues (greenish yellow in the photographs) with one exception. Specifically, the DNase I-positive control treatment consistently failed in LO tissue nuclei although it worked normally with surrounding tissue. As seen in the figure, the positive control for gill tissue gave a typical positive TUNEL reaction (similar to that in muscle tissue, epithelial tissue, etc., on the same slide) while the grossly normal nuclei of LO tissue (inside or outside spheroids) remained negative, although abnormal nuclei in spheroids did give a TUNEL-positive reaction 


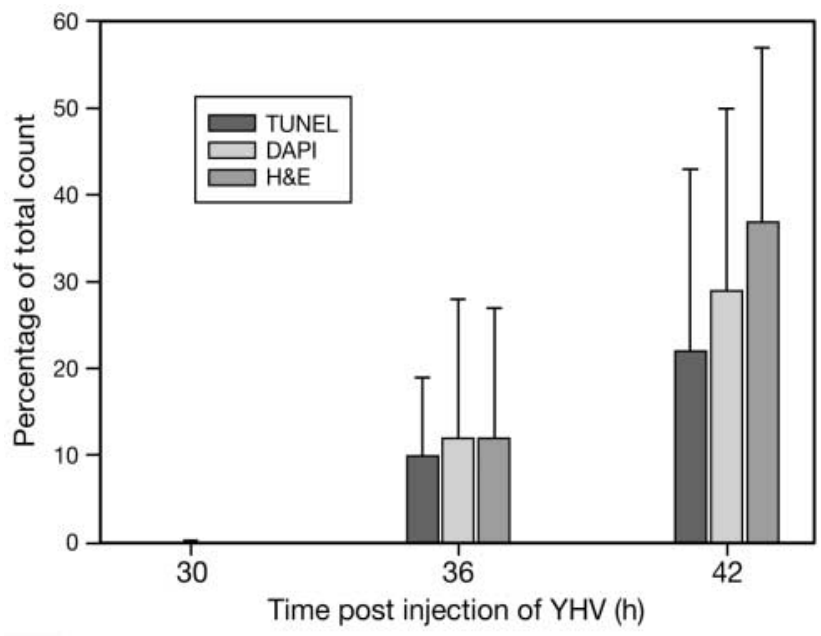

Fig. 4. Percentage of presumably apoptotic hemocytes in YHV-injected shrimp detected by 3 different methods (H\&E staining, DAPI staining and TUNEL) at different times postinjection (p.i.). Test positive nuclei were seen only from $30 \mathrm{~h}$ p.i. and numbers increased steadily thereafter. Each bar represents the mean from 8 shrimp

monoclonal antibody described by Sithigorngul et al. (2000) and we found that the tissues (including LO spheroids) were negative for YHV before the start of our experiments and that controls remained so throughout. The results suggested that, even though our DNase I treatment failed, DNA fragmentation that had occurred endogenously in the LO tissue (whatever the cause) was still detectable by TUNEL assay. The

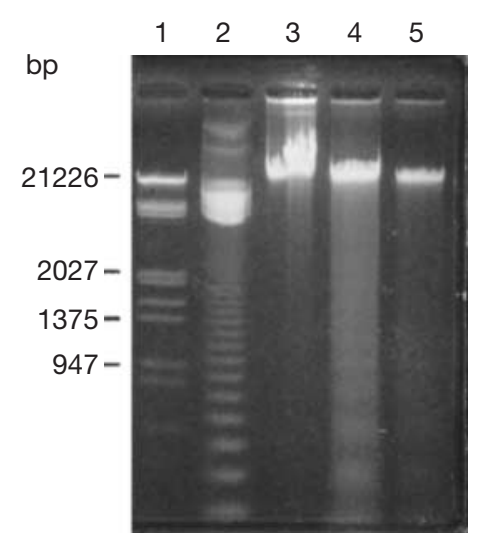

Fig. 5. Agarose gel electrophoresis of a Penaeus monodon hemocyte DNA extract prepared at $48 \mathrm{~h}$ p.i. Lane 1: marker $\lambda$ DNA cut with ECoRI and HindIII; lane 2: 123 base pair marker (ladder marker); lane 3: hemocyte DNA from normal shrimp; lane 4: hemocyte DNA from YHV-infected shrimp; lane 5: 1:2 diluted solution of hemocyte DNA from YHVinfected shrimp. A DNA ladder pattern of approximately 200 base pair interval can be clearly seen in lane 4. Similar but fainter bands were observed in lane 5 , but they are difficult to see in the black and white print failure of DNase I to function in LO tissue requires further investigation but may have resulted from the presence of a tissue-specific inhibitor.

Under TEM, apoptotic bodies frequently occurred in clusters in intercellular spaces, where they were subsequently phagocytosed by neighboring cells. Thus, many of the cytoplasmic basophilic inclusion bodies characteristic of YHV infection with H\&E staining (Boonyaratpalin et al. 1993, Chantanachookin et al. 1993, Nash et al. 1995 ) are likely to be phagocytosed apoptotic bodies. As found previously (Flegel \& Pasharawipas 1998), there was no evidence of the type of inflammatory response usually elicited by coagulative necrosis (Kerr et al. 1972). In addition, the pathological changes began in some LO cells as early as $12 \mathrm{~h}$ p.i., before the appearance of virions in the cytoplasm, suggesting that viral assembly may not be a prerequisite for them. Many previous studies have shown that viral components are capable of inducing apoptosis (Everett $\&$ McFadden 1999). For example, the E2 structural protein of Sinbis virus alone can induce apoptosis in the absence of viral replication, as can the proteins Gp120 or Gp41 of human immunodeficiency virus-1 (Everett \& McFadden 1999). It is likely that the apoptotic shrimp cells we observed were infected with YHV and that viral replication steps preceding the development of identifiable viral components had been initiated. Whether apoptosis can be initiated by viral proteins alone will require further investigation.

Additional evidence of apoptosis was obtained from the ladder pattern of chromosomal DNA fragments separated by intervals of 180 to $200 \mathrm{bp}$ resolved by gel electrophoresis of hemocyte DNA from YHV-infected shrimp. This phenomenon is similar to that resulting from cutting by endonucleases specific for doublestranded DNA at inter-nucleosomal positions in complete chromatin, and it is considered to be a marker for apoptosis in other organisms (Arends et al. 1990). The occurrence of these DNA ladders in DNA extracts of hemocytes from YHV-infected shrimp suggests that death of hemocytes is mediated by endonucleolytic cleavage of their DNA, as in apoptotic cells. DNA cleavage has been reported to occur through $\mathrm{Ca}^{++}$and $\mathrm{Mg}^{++}$-dependent or -independent endonucleases that cut chromosomal DNA at the linker region between nucleosomes to give $\mathrm{OH}^{-}$at the 3 ' ends of the cut DNA (see review by Sikorska \& Walker 1998). In non-apoptotic cells, the enzyme caspase-activated deoxyribonuclease (CAD) is present as an inactive complex controlled by its inhibitor $\left(\mathrm{I}^{\mathrm{CAD}}\right)$. During apoptosis, $\mathrm{I}^{\mathrm{CAD}}$ is activated by caspase and this, in turn, frees CAD to function as an endonuclease (see review by Thornberry \& Lazebnik 1998). The next logical step would be to identify these enzymes in apoptotic shrimp cells. 

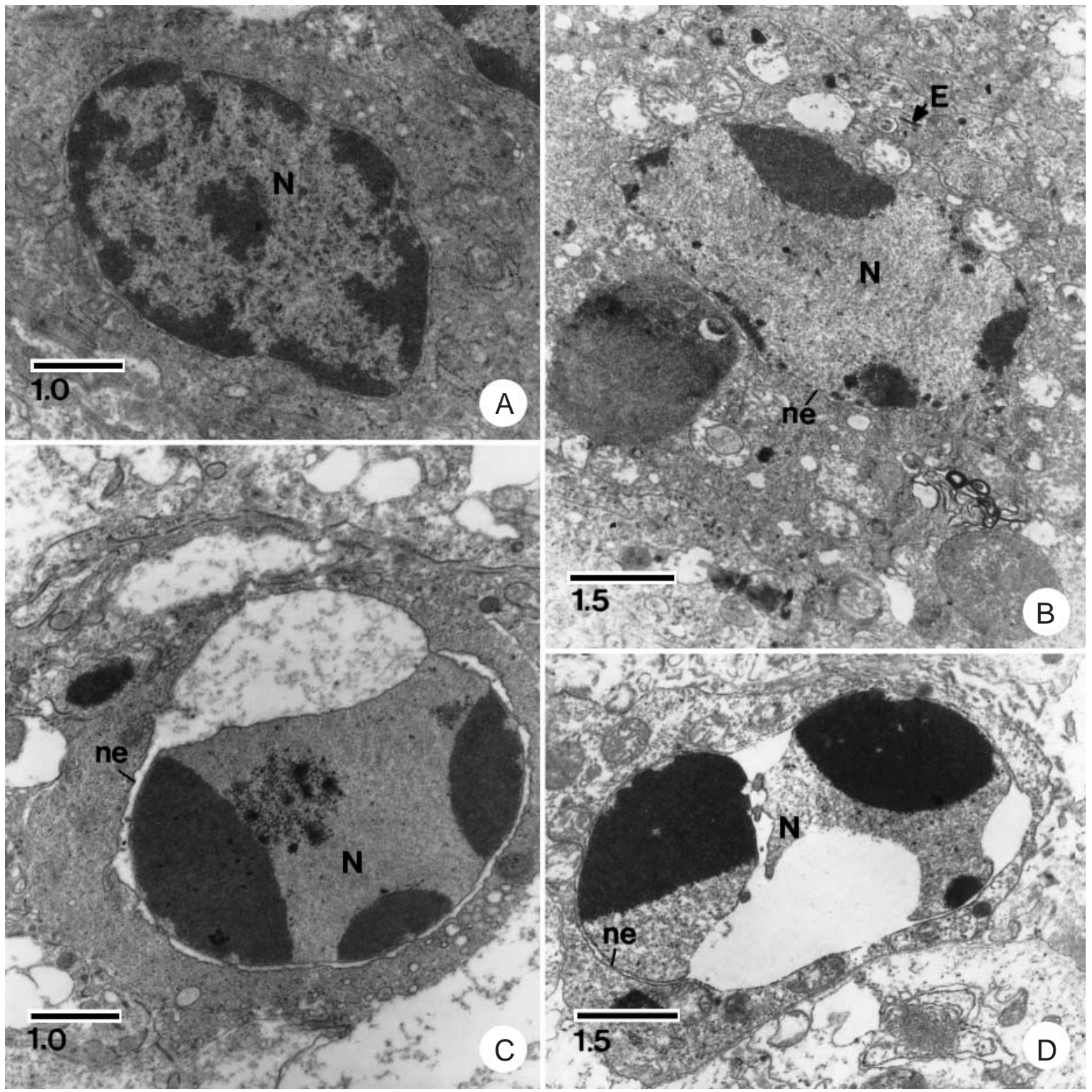

Fig. 6. Transmission electron photomicrograph of the LO of normal and YHV-infected Penaeus monodon at $12 \mathrm{~h}$ p.i. Cells from normal shrimp contained nuclei with heterochromatin distributed in peripheral patches and as a central mass (A). In the YHV-injected shrimp, normal cells dominated but a few had nuclear chromatin condensed and marginated in sharply delineated masses abutting the nuclear envelope (B to D). The cytoplasm was also markedly condensed. There was no evidence of unenveloped or enveloped viral particles in these or other cells. E: enveloped YHV particle; N: nucleus; ne: nuclear envelope. All scale bars shown are in micrometers

Altogether, the data strongly suggest that cell death in YHD results mainly from apoptosis and that high numbers of apoptotic cells may be the primary cause of death in YHV-infected shrimp. No specific tests were undertaken to determine this. However, moribund shrimp have extensive deterioration of vital tissues such as the hemolymph, gills, heart and LO, suggesting that many essential bodily functions have been severely compromised. This probably results in gross signs of lethargy and weakness and it is reasonable to suggest that further progressive deterioration could lead to the collapse of organ functions followed by death.

The results for YHV are similar to those reported for field and laboratory infections with WSSV (Henderson \& Stuck 1999, Sahtout et al. 2001), where there are also indications that shrimp mortality is correlated with high numbers of apoptotic cells. Thus, 2 very different 


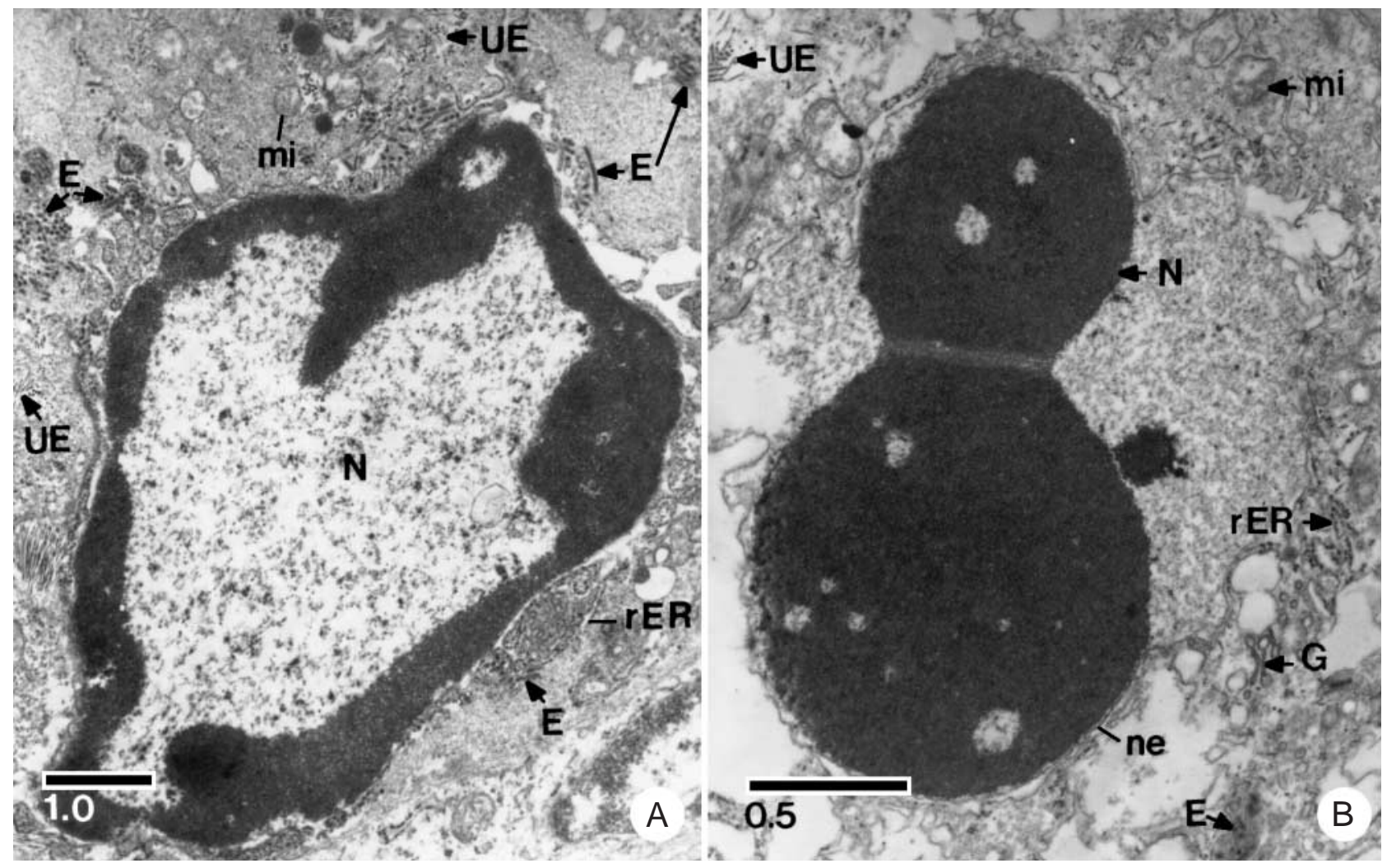

Fig. 7. Transmission electron photomicrograph of the LO of YHV-infected Penaeus monodon at 24 to 36 h p.i. Cells with marginated and condensed heterochromatin were seen (A), similar to those from $12 \mathrm{~h} \mathrm{p.i.} \mathrm{except} \mathrm{that} \mathrm{they} \mathrm{were} \mathrm{more} \mathrm{abundant} \mathrm{and}$ more condensed (B), and they were found in the presence of unenveloped (UE) and enveloped (E) YHV particles. YHV virions were frequently observed in the cytoplasm $(E)$. Despite the rather severe pathological changes in the nucleus, the nuclear envelope (ne) and cytoplasmic organelles such as mitochondria (mi), ribosomes and rough endoplasmic reticulum (rER) were relatively intact (A) until late in the transformation (B). G: Golgi complex; N: nucleus. All scale bars shown are in micrometers

viruses (i.e. one DNA and the other RNA) appear to cause death in a similar way, and this suggests that there may similar underlying mechanisms in the host reaction to both infections. This would be in keeping with the viral accommodation theory (Flegel \& Pasharawipas 1998, Flegel 2001), which proposes that apoptosis is the general cause of shrimp death from viral infections.

Previous studies have found that apoptosis is controlled by several gene products that interact directly with components of highly conserved biochemical pathways to regulate cell death (Everett \& McFadden 1999). Thus, by inference, death by apoptosis in Penaeus monodon infected by YHV may be, in part, genetically determined, and genetic factors may explain the phenomenon of tolerance reported to occur with YHD (Pasharawipas et al. 1997) within approximately $1.5 \mathrm{yr}$ of its catastrophic appearance in southern Thailand. By that time, most farmers were obtaining good harvests in spite of the presence of YHV in their ponds, as revealed by TEM. If apoptosis is the cause of death in YHV-infected shrimp, its induction must be influenced by both virus and host gene products pivotal in determining the death or survival of infected shrimp. It could be reasoned that shrimp would survive YHV infection if they or their pathogens possessed active genes that inhibit apoptosis. It has been proposed that tolerance develops in situations where an early viral binding step results in specific memory that suppresses apoptosis upon subsequent or concurrent viral infection that might otherwise lead to death (Flegel \& Pasharawipas 1998). If this hypothesis is correct, it is possible that many carrier species with active YHV infections have infected cells with large numbers of virions but possess genes that inhibit apoptosis and thus prevent death.

Studying viral induction or inhibition of apoptosis is an important tool for dissection of the cell death pathway, and such studies might give insights into possible therapeutic interventions in situations where inhibitory mechanisms fail. Recently, a number of low molecular weight gene products have been used to inhibit or 


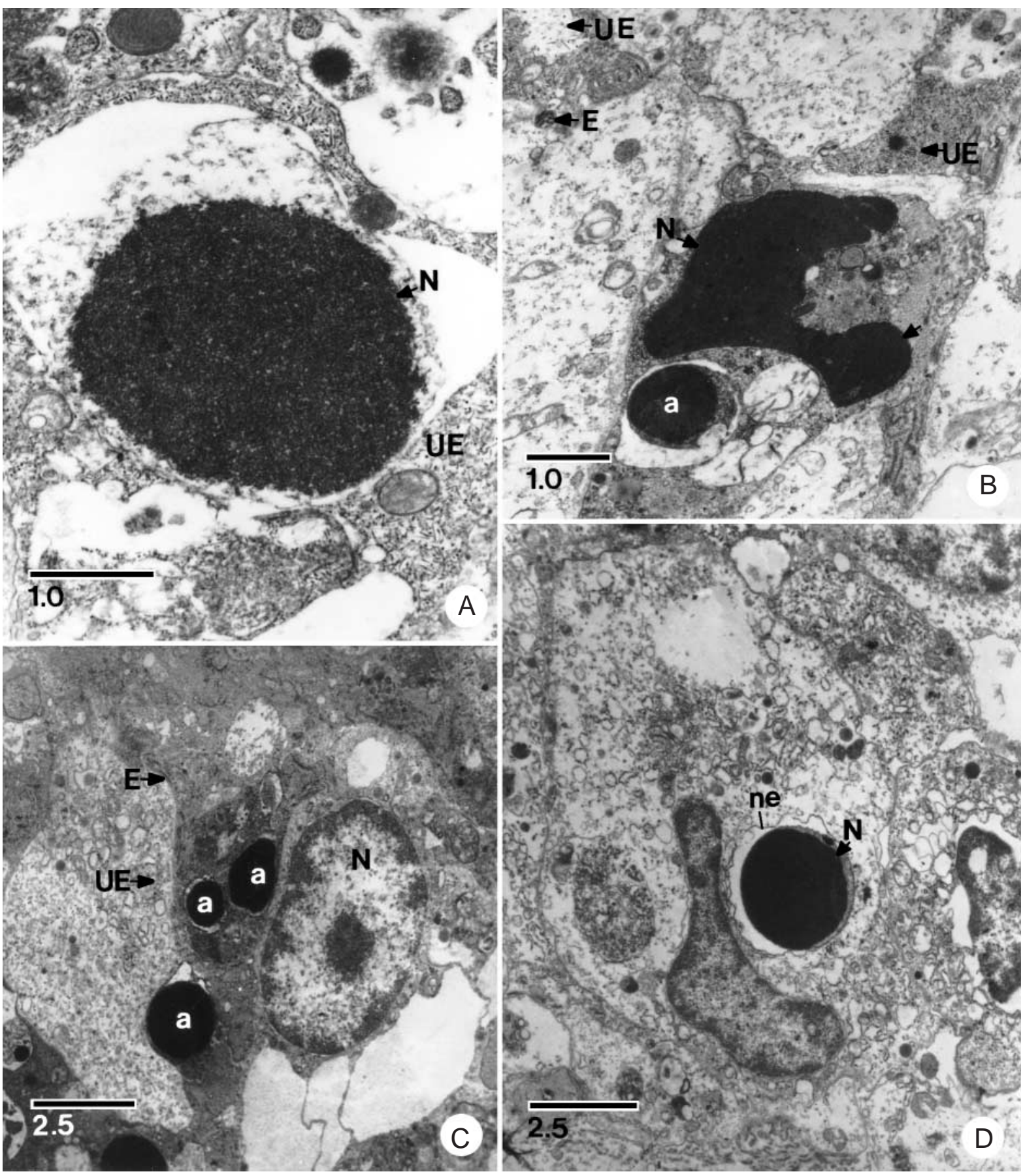

Fig. 8. Transmission electron photomicrograph of the LO of YHV-infected Penaeus monodon at 40 to $48 \mathrm{~h}$ p.i. Many electrondense pyknotic nuclei (A, D) and round structures surrounded by narrow electron-lucent spaces were observed (B, C). The latter were frequently interpreted as 'apoptotic bodies' (a). They were frequently observed in clusters in intercellular spaces. They and pyknotic nuclei were often phagocytosed by neighboring cells and subsequently appeared to undergo degenerative changes within phagosomes. E: enveloped virions; N: nucleus; ne: nuclear envelope; UE: unenveloped virions. All scale bars shown are in micrometers

enhance this fundamental cellular process, and so apoptosis has now become amenable to pharmacological manipulation (Kinloch et al. 1999). Thus, further un- derstanding of apoptosis in experimental and natural YHV infections may lead to the development of feed additives that could prevent or stem YHV disease. 
Acknowledgements. The authors would like to thank Anchalee Pongsa-Asawapaiboon for assistance in preparing the figures. Support for this investigation was through grants from the Institution Strengthening Program, Faculty of Science, Mahidol University, the Thai National Center for Genetic Engineering and Biotechnology, and the National Institute of Fisheries, Arlington, Virginia, USA.

\section{LITERATURE CITED}

Anggraeni MS, Owens L (2000) The haemocytic origin of lymphoid organ spheroid cells in the penaeid prawn Penaeus monodon. Dis Aquat Org 40:85-92

Arends MJ, Moris RG, Wyllie AH (1990) Apoptosis the role of endonuclease. Am J Pathol 136:593-608

Bell TA, Lightner DV (1988) A handbook of normal shrimp histology. World Aquaculture Society, Baton Rouge, LA

Boonyaratpalin S, Supamataya K, Kasornchandra J, Direkbusarakom S, Ekpanithanpong U, Chantanachookin C (1993) Non-occluded baculo-like virus the causative agent of yellow-head disease in the black tiger shrimp Penaeus monodon. Fish Pathol 28:103-109

Chantanachookin C, Boonyaratpalin S, Kasornchandra J, Direkbusarakom S, Dkpanithapong U, Supamataya K, Sriurairatana S, Flegel TW (1993) Histology and ultrastructure reveal a new granulosis-like virus in Penaeus monodon affected by yellow-head disease. Dis Aquat Org 17:145-157

Cowley JA, Dimmock CM, Wongteerasypaya C, Boonsaeng V, Panyim S, Walker PJ (1999) Yellow head virus from Thailand and gill associated-virus from Australia are closely related but distinct prawn viruses. Dis Aquat Org 36:153-157

Cowley JA, Dimmock CM, Spann KM, Walker PJ (2000a) Detection of Australian gill-associated virus (GAV) and lymphoid organ virus (LOV) of Penaeus monodon by RT-nested PCR. Dis Aquat Org 39:159-167

Cowley JA, Dimmock CM, Spann KM, Walker PJ (2000b) Gill associated virus of Penaeus monodon prawns: an invertebrate virus with ORF1a and ORF1b genes related to arteriand coronaviruses. J Gen Virol 81:1473-1484

Everett H, McFadden G (1999) Apoptosis: an innate immune response to virus infection. Trends Microbiol 7:160-165

Flegel TW (2001) The shrimp response to viral pathogens. In: Browdy CL, Jory DE (eds) The new wave. Proceedings of the special session on sustainable shrimp aquaculture, Aquaculture 2001. World Aquaculture Society, Boca Raton, LA, p 190-214

Flegel TM, Pasharawipas T (1998) Active viral accommodation: a new concept for crustacean response to viral pathogens. In: Flegel TW (ed) Advances in shrimp biotechnology. National Center for Genetic Engineering and Biotechnology, Bangkok, p 245-250

Garvieli Y, Sherman Y, Ben-Sasson SA (1992) Identification of programmed cell death in situ via specific labeling of nuclear DNA fragmentation. J Cell Biol 119:493-501

Hasson KW, Lightner DV, Mohney LL, Redman RM, White B (1999) Role of lymphoid organ spheroids in chronic Taura syndrome virus (TSV) infections in Penaeus vannamei. Dis Aquat Org 38:93-105

Editorial responsibility: Otto Kinne, Oldendorf/Luhe, Germany
Henderson T, Stuck K (1999) Induction of apoptosis in response to white spot syndrome virus in the Pacific white shrimp, Penaeus vannamei. Abstract \#67. Aquaculture America 1999, Tampa, Florida. World Aquaculture Society, Baton Rouge, LA

Kasornchandra J, Supamattaya K, Boonyaratpalin S (1995) Electron microscopic observations on the replication of yellow-head baculovirus in the lymphoid organ of Penaeus monodon. Asian Shrimp News 15:2-3

Kerr JFR (1971) Shrinkage necrosis: a distinct mode f cellular death. J Pathol 105:13-20

Kerr JFR, Wyllie AH, Currie AR (1972) Apoptosis: a basic biological phenomenon with wide ranging implications in tissue kinetics. Br J Cancer 26:239-257

Kinloch RA, Treheme JM, Furness LM, Hajimohamadreza I (1999) The pharmacology of apoptosis. Trends Pharmacol Sci 20:35-42

Lightner DV (1996) A handbook of shrimp pathology and diagnostic procedures diseases of cultured penaeid shrimp. World Aquaculture Society, Baton Rouge, LA

Limsuwan C (1991) Handbook for cultivation of black tiger prawns. Tansetakit Co. Ltd, Bangkok

Nash GL, Akarajamorn A, Withyachumnarnkul B (1995) Histology and rapid haemocytic diagnosis of yellow-head disease in Penaeus monodon. In: Shariff M, Arthur JR, Subasinghe RP (eds) Diseases in Asian aquaculture II. Fish Health Section, Asian Fisheries Society, Manila, p 89-98

Pasharawipas T, Flegel TW, Shiurairatana S, Morrison DJ (1997) Latent yellow-head infections in Penaeus monodon and implications regarding disease resistance or tolerance. In: Flegel TW, Menasveta P, Paisarnrat S (eds) Shrimp biotechnology in Thailand. National Center of Genetic Engineering and Biotechnology, Bangkok, p 45-53

Paterson WD, Stewart JE (1974) In vitro phagocytosis by hemocytes of American lobster (Homorus americanus) J Fish Res Board Can 31:1051-1056

Sambrook J, Fritsch EF, Maniatis T (1989) Molecular cloning, a laboratory manual, 2nd edn. Cold Spring Harbor Laboratory Press, Cold Spring Harbor, NY, p 9.16-9.30

Sahtout AH, Hassan MD, Shariff M (2001) DNA fragmentation, an indicator of apoptosis in cultured black tiger shrimp Penaeus monodon infected with white spot syndrome virus. Dis Aquat Org 44:155-159

Sikorska M, Walker PR (1998) Endonuclease activities and apoptosis In: Lockchin RA, Zakeri Z, Tilly JL (eds) When cells die. Wiley-Liss, London, p 211-242

Sithigorngul P, Chauychuwong P, Sithigorngul W, Longyant S, Chaivisuthangkura P, Menasveta P (2000) Development of a monoclonal antibody specific to yellow head virus (YHV) from Penaeus monodon. Dis Aquat Org 42:27-34

Tang KFJ, Lightner DV (1999) A yellow head virus gene probe: nucleotide sequence and application for in situ hybridization. Dis Aquat Org 35:165-173

Thornberry NA, Lazebnik Y (1998) Caspases: enemies within. Science 281:1312-1316

Wongteerasupaya C, Sriurairatana S, Vickers JE, Akarajamorn A, Boonsaeng V, Panyim S, Tassanakajon A, Tassanakajon A, Withyachumnarnkul B, Flegel TW (1995) Yellow-head virus of Penaeus monodon is an RNA virus. Dis Aquat Org 22:45-50

Submitted: March 28, 2001; Accepted: September 4, 2001

Proofs received from author(s): March 4, 2002 